\title{
TANGGAPAN SISWA TERHADAP MANFAAT KEGIATAN EKSTRAKURIKULER OLAHRAGA DALAM PENGEMBANGAN PRESTASI DAN POTENSI DIRI
}

\author{
M. Yahya ${ }^{1)}$ Amirzan ${ }^{2)}$ \\ 1) Fakultas Keguruan dan Ilmu Pendidikan, Universitas Jabal Gafur \\ ${ }^{2)}$ Fakultas Keguruan dan Ilmu Pendidikan, Universitas Jabal Gafur \\ 1) Yahya_aka@yahoo.co.id \\ 2) amirzan_masry@yahoo.co.id
}

\begin{abstract}
ABSTRAK
Pada penelitian yang berjudul "Tanggapan Siswa Terhadap Manfaat Kegiatan Ekstrakurikuler Olahraga dalam Pengembangan Prestasi dan Potensi Diri", bertujuan ingin mengetahui sejauh mana pemahaman siswa pada sekolah jenjang paling bawah tersebut terhadap danpak atau pengaruh dari kegiatan ekstrakurikuler olahraga yang diselenggarakan di sekolah mereka, sperti difahami bahwa kegiatan ekstrakurikuler dan potensi olahraga yang siswa miliki. Apakah dengan kegiatan ekstrakurikuler gersebut dapat merubah prestasinya ke arah yang lebih baik ataupun paling tidak ia menemukan potensi dan bakat yang terpendam selama ini, sehingga ia akan selalu menggeluti cabang olahraga tersebut. Penelitian ini termasuk dalam penelitian deskreptif. Sampel penelitian adalah siswa kelas VI SD Negeri Pasi Rawa Kecamatan Pidie Kabupaten Pidie, yang berjumlah sebanyak 32 siswa. Teknik pengumpulan data dalam penelitian ini adalah Pengumpulan data dengan mengedarkan angket yang berisi sejumlah pertanyaan yang terkait dengan asumsi siswa terhadap manfaat kegiatan ekstrakurikuler olahraga terhadap prestasi dan penggalian potensi mereka, angket yang digunakan adalah angket tertutup dan angket terbuka. Hasil penelitian menunjukan bahwa 59,30\% siswa atau lebih dari setengah siswa menjawab senang mengikuti kegiatan ekstrakurikuler disekolahnya, tanapa paksaan siapapun serta mereka memahami bahwa kegiatan ekstrakurikuler dapat meningkatkan prestasi serta mampu menggali potensi olahraga yang mereka miliki. Sehingga kedepannya diharapkan kegiatan ini terus dapat dilaksanakan oleh para guru, terutama guru Penjasorkes, terutama untuk menanamkan dasar-dasar olahraga pada siswanya, serta membibing dan meningkatkan prestasi siswa sedini mungkin.
\end{abstract}

Kata Kunci : Tanggapan, Manfaat, Kegiatan Ekstrakurikuler Olahraga

\section{PENDAHULUAN}

Pengembangan sikap dan kemampuan serta memberikan pengetahuan dan keterampilan dasar yang telah menempatkan pendidikan di sekolah dasar menjadi amat strategis, sehingga penyelenggaraannya harus dilakukan secara baik pula. Telaah yang seksama tentang upaya menuju ke arah peningkatan mutu pendidikan sekolah dasar pada saat ini dipandang tepat dan relevan, Sehingga berbagai mata pelajaran telah disusun untuk meningkatkan kwalitas dasar manusia Indonesia.

Diantara mata pelajaran yang ada di sekolah dasar adalah mata pelajaran Pendidikan Jasmani Kesehatan dan Olahraga
(Penjasorkes/PJOK), yang termasuk salah satu mata pelajaran yang disajikan dengan keterbatasan waktu. Karena waktu yang dialokasikan untuk mata pelajaran pendidikan jasmani sangat terbatas, maka guru diharapkan dapat menyusun kegiatankegiatan pendukung pencapaian pengembangan ketrampilan anak, seperti kegiatan ekstrakurikuler. Dalam upaya mencapai keseluruhan kompetensi di dalam kurikulum yang kegiatannya dapat dilaksanakan pada waktu luang/senggang seperti sore hari, hari libur.

Pendidikan jasmani adalah suatu proses pendidikan seseorang sebagai perorangan maupun sebagi anggota 
masyarakat yang dilakukan secara sadar dan sistematis melalui kegiatan jasmani yang intensif dalam rangka memperoleh peningkatan kemampuan dan keterampilan jasmani. Pertumbuhan kecerdasan dan pembentukan watak agar siswa dapat menambah pengetahuan dan pengajaran berbagai keterampilan, maka pihak sekolah mengadakan kegiatan ekstrakurikuler kegiatan ekstrakurikuler tersebut tidak hanya mencakup kegiatan non olahraga saja akan tetapi juga kegiatan ekstrakurikuler olahraga karena kegiatan ekstrakurikuler olahraga juga membantu siswa untuk meningkatkan keterampilan yang ada dalam mata pelajaran pendidikan jasmani sementara itu ruang lingkup olahraga terbagi tiga tujuan seperti yang tercantum dalam UU RI Non 3 tahun 2005 tentang sistem keolahragaan nasional pasal 17 yang menyebutkan bahwa olahraga mencakup olahraga pendidikan (pendidikan Jasmani) olahraga rekreasi dan olahraga prestasi.

Akibat dari keterbatasan waktu dalam pembelajaran pendidikan jasmani tersebut maka berbagai keterampilan olahraga yang merupakan ciri dari pembelajaran pendidikan jasmani tidak dapat dipelajari dengan secara maksimal hal ini berdampak terhadap tingkat daya serap materi yang terwujud pada penguasaan keterampilan yang diperoleh akibatnya hasil belajar pendidikan jasmani tidak sesuai dengan yang diharapkan.

Kegiatan ekstrakurikuler olahraga yang diselengarakan di sekolah dasar merupakan kegiatan yang mempunyai potensi besar bagi masa depan kemajuan prestasi dunia olahraga, kenyataan penggarapan kegiatan ekstrakurikuler ini belum begitu terprongram secara baik, agar kegiatan ini dapat berjalan sesuai harapan kedepanya, maka suatu hal perlu diperhatikan yaitu bagaimana dengan partisipasi siswa dalam mengikuti kegiatan ekstrakurikuler olahraga tersebut. Apakah mereka dengan sukarela mengikuti kegiatan tersebut dengan harapan dapat mengembangkan atau meningkatkan potensi keterampilan dasar olahraga yang mereka miliki, atau keikut sertaan mereka hanya karena terpaksa, atau karena motivasi dari luar, seperti paksaan dari para guru maupun orang tua siswa.

Selanjutnya terkait kemampuan guru untuk melaksanakan kegiatan tersebut dengan baik, sehingga dapat meningkatkan ketertarikan siswa, serta didukung oleh fasilitas yang memenuhi syarat sefrta adnya dukungan dari pihak-pihak terkait, seperti kepala sekolah dan dinas-dinas terkait. Berdasarkan latar belakang masalah yang telah diuraikan di atas maka rumusan masalah dalam penelitian ini adalah:

Bagaimanakah tanggapan siswa SD Negeri Pasi Rawa Kecamatan Pidie Kabupaten Pidie terhadap manfaat dalam mengikuti kegiatan ekstrakurikuler olahraga terhadap peningkatan prestasi dan potensi diri dalam bidang olahraga. Selanjutnya cabang-cabang olahraga apa saja yang diminati siswa SD Negeri Pasi Rawa Kecamatan Pidie Kabupaten Pidie dalam mengikuti kegiatan ekstrakurikuler olahraga.

\section{Landasan Teoritis \\ 1. Pengertian Tangapan}

Tanggapan yaitu suatu bayangan yang tinggal dalam ingatan setelah kita melakukan pengamatan (Bigoteta1,1950:72) Tanggapan dapat dibedakan menjadi tiga bagian, yaitu (1) Tanggapan masa lampau atau tangapan ingatan, (2) Tanggapan masa datang atau tangapan mengantisipasikan (3) Tanggapan masa kini atau tangapan representatif (tangapan mengimajinasikan)

Tangapan pada hakikatnya adalah merupakan proses penilaian seseorang terhadap objek tertentu menurut Uoung (1996) tanggapan merupakan aktifitas pengindra mengintegrasikan dan memberi penilaian pada objek-objek fisik maupun objek sosial yang ada di lingkunganya menurut wagito (1981) menyatakan bahwa tangapan merupakan, proses psikologis dan hasil dari pengindraan serta proses terhirdan kesadaran, sehingga membentuk proses berpikir, dalam proses tanggapan diajurkan untuk memberi penilaan terhadap suatu objek yang bersifat positif maupun negatif dengan 
adanya tanggapan maka terbentuknya suatu kecendrungan yang stabil untuk berlaku atau bertindak secara tertentu dalam situasi tertentu pula, dengan demikian persepsi merupakan suatu fungsi biolodis (melalui organ-organ) yang memukakan individu menerima dan mengelola informasi dari lingkungan dan mengadakan perubahanperubahan dari lingkungannya. (Eytonck, 1972) istilah tanggapan merupakan proses aktifitas seorang memberikan kesan, penelitian pendapat merasakan menginterprestasikan suatu bedasarkan informasi yang ditampilkan dari informasi lain adanya tangapan sangat penting agar dapat menumbuhkan komunikasi aktif, sehinga dapat meningkatkan kapasitas belajar dikelas oleh karena itu menurut walgito kesan yang pertama untuk menmcapai suatu keberhasilan tangapan seorang seorang mendapatkan informasi dan peristiwa-peristiwa. Menurut muliadi (1989) dipengaruhi olah tiga faktor yaitu (a). Orang yang membentuk tangapan itu sendiri khusunya kondisi item (kebutuhan, kelelahan, sikap mental, minat motivasi) harapan pengalaman masa lalu dan berkepribadian.

Banyak ahli yang mencoba membuat definisi dari tangapan Beberapa di antaranya adalah tangapan ialah interpretasi tentang apa yang diinderakan atau dirasakan individu Bower (1978) Tangapan merupakan proses yang terjadi di dalam diri individu yang dimulai dengan diterimanya rangsang, sampai rangsang itu disadari dan dimengerti oleh individu sehingga individu dapat mengenali dirinya sendiri dan keadaan di sekitarnya Bimo Walgito (1997) "Tangapan merupakan proses pengorganisasian dan penginterpretasian terhadap stimulus oleh organisme atau individu sehingga didapat sesuatu yang berarti dan merupakan aktivitas yang terintegrasi dalam diri individu" Davidoff (1958) "Tangapan merupakan suatu proses yang dimulai dari penglihatan hingga terbentuk persepsi yang terjadi dalam diri individu sehingga individu sadar akan segala sesuatu dalam lingkungannya melalui indera- indera yang dimilikinya". Dengan demikian proses lahirnya persepsi tersebut melibatkan berbagai panca indra seperti mata dan telinga.

\section{Kegiatan Ekstrakurikuler}

\subsection{Pengertian Ekstrakurikuler}

Kegiatan ekstrakurikuler merupakan kegiatan yang dilakukan di luar jam aktif sekolah atau di sekolah untuk memperluas wawasan dan pengetahuan siswa, Menurut Sutisna (1979:52) ekstrakurikuler adalah sebagai alat yang amat penting untuk tercapai tujuan-tujuan pendidikan yang berati dan tidak sekedar untuk menjadi sumber-sumber hiburan bagi murid, Sementara itu menurut Ayarifuddin dan Asmu (1982:45) dalam pelaksanaan kurikuler menyatakan program ekstrakurikuler adalah suatu program yang dapat menunjang tercapainya tujuan pendidikan, di mana hal-hal yang tidak dapat diselesaikan.

Dalam program yang telah ditentukan jam pelajaran sekolah, dapat diberikan diluar jam akti sekolah atau pada waktu libur sekolah, Dari pengertian ekstrakurikuler menurut beberapa ahli di atas maka dapat di kemukakan bahwa ekstrakurikuler adalah kegiatan yang dilakukan di luar jam aktif yang dilakukan di sekolah atau di luar sekolah dengan tujuan memperluas wawasan dan pengetahuan siswa, Dengan kata lain ekstrakurikuler merupakan aktifitas tanbahan, pelengkap bagi siswa disamping jam wajib belajar.

Ekstrakurikuler adalah kegiatan pelajaran yang di lakukan di luar jam pelajaran biasa kegiatan tersebut biasanya di laksanakan pada sore hari keterbatasan waktu berolahraga yang dilakukan secara formal sangat menghambat tercapainya pembinaan secara maksimal untuk perkembangan dan pertumbuhan siswa oleh karena itu sering sekali ataupun waJib diadakan kegiatan di luar jam sekolah untuk memaksimalkan kegiatan bagi siswa yang mengikutinya walaupun kegiatan tersebut tidak formal dengan adanya kegiatan yang dilakukan diluar sekolah maka siswa dapat menyalurkan, memaksimalkan dan 
mengembangkan kemampuan beserta bakatnya yang terpendam di dalam dirinya masing masing melalui ekstrakurikuler siswa dapat benar-benar menjadi manusia yang intensif siswa dapat belajar untuk menghormati keberhasilan orang lain bersikap sportif, berjuang intuk mencapai prestasi secara jujur, Ekstrakurikuler Adalah kegiatan yang diselenggarakan di luar jam pelajaran yang tercantum dalam susunan program sesuai dengan keadaan dan kebutuhan sekolah (Wandjosumidjo, 2002:215) Sedangkan menurut (Daryanto, 1996:68),

Ekstrakurikuler adalah kegiatan untuk membantu memperlancar perkembangan individu murid sebagai manusia seutuhnya, Dan menurut Poerwadarminta (1986:269), Ekstrakurikuler adalah tambahan yang bersangkutan dengan kurikulum, sedangkan menurut pelaksanaan kurikulum 1994 adalah pengertian Ekstrakurikuler olahraga adalah merupakan kegiatan yang dilakukan diluar jam sekolah untuk memperluas wawasan pengetahuan dan berbagai mata pelajaran dan kurikulum, Departemen Pendidikan dan Kebudayaan, (1990:10) Definisi kegiatan ekstrakurikuler adalah suatu kegiatan yang dilakukan pada jam diluar sekolah (dilakukan termasuk hari libur) yang dilakukan di luar sekolah dan bertujuan memperluas pengetahuan siswa, mengenal dan menambah berbagai kegiatan olahraga, menyalurkan bakat dan minat serta melengkapi upaya pembinaan seutuhnya, kegiatan ini dilakukan secara berkala atau hanya dalam kurun waktu dan. ikut dinilai (Soegiyono, 1992:30).

Kegiatan ekstrakurikuler, yaitu kegiatan yang dilakukan diluar jam pelajaran tatap muka, dilaksanakan di sekolah maupun di luar sekolah untuk memperkaya dan memperluas wawasan pengetahuan atau peningkatan nilai atau sikap, dalam rangka penerapan pengetahuan dari kemampuan yang telah dipelajari dari berbagai mata pelajaran dalam kurikulum.

Ada dua macam sumber yang memberikan rumusan tentang pengertian ekstrakurikuler, yaitu: (a). SK Dirjen Dikdasmen Nomor 226/c/Kep/1992 Berdasarkan SK tersebut dirumuskan bahwa ekstrakurikuler adalah kegiatan diluar pelajaran biasa dan pada waktu libur sekolah yang dilakukan baik disekolah ataupun diluar sekolah, dengan tujuan untuk memperdalam dan memperluas pengetahuan siswa, mengenal hubungan antara berbagai pelajaran, menyangkut bakat dan minat, serta melengkapi upaya pembinaan manusia seutuhnya. (b). Lampiran SK Mendikbud Nomor 060/U/1993, Nomor 061/U/1993 dan Nomor 080/U/1993 Berdasarkan ketiga SK Mendikbud tersebut dikemukakan, bahwa kegiatan ekstrakurikuler adalah kegiatan yang diselenggarakan diluar jam pelajaran yang tercantum dalam susunan program sesuai dengan keadaan dan kebutuhan sekolah, Kegiatan ekstrakurikuler merupakan kegiatan pengayaan dan kegiatan perbaikan yang berkaitan dengan program kurikuler memperhatikan kedua sumber tersebut, ada perbedaan rumusan dalam, kalimat, tetapi makna yang terkandung didalamnya sama keduanya menekankan bahwa kegiatan ekstrakurikuler mengacu pada mata pelajaran dalam rangka pengayaan dan perbaikan, serta usaha pembianaan manusia atau upaya pemantapan pembentukan kepribadian siswa. Kegiatan ekstrakurikuler dapat dilihat beberapa aspek:

1. Dari tujan ekstrakurikuler melaksanakan pada penyaluran dan pemusatan bakat atau potensi perorangan melalui kegiatan perorangan yang intensif.

2. Dilihat dari keterlibatan anak didik, bahwa dalam kegiatan ekstarkurikuler tidak ada pelaksanaan, Keterlibatan mereka secara suka rela, bahkan bedasarkan kebutuhan mereka sendiri Kegiatan ekstrakurikuler merupakan prongram yang berorientasi pada anak didik.

3. Dari sudut kegiatan yang dilakukan, prongrm ekstrakurikuler dapat mencakup berbangai eksrakurikuler kegiatan yang menarik minat para siswa. 
Pelaksanaan kegiatan ekstarkurikuler merupakan suatu perencanaan, yang sesuai dengan kebijaksanaan lembaga pendidikan atau sekolah yang bersangkutan. Hal ini diperlukan untuk mendapatkan dukungan dari sumber-sumber pendukung, seperti sarana dan fasilitas, biaya serta tenaga pernbina, dalam melaksanaan kegiatan ekstrakurikuler semua sekolah mempunyai penekanan tertentuada sekolah yang mengutamakan olahraga dan ada juga sekolah yang mengutamakan cendrung kepalatihan ketrampilan tanggan untuk siswa, Ditinjau dari segi pelaksanaan kegiatan ekstra kurikuler ada yang bersifat kompetitif dan ada juga yang bersifat non kompetitif, Kegiatan yang bersifat kompetitif biasanya melaksanakan dengan tujuan mencapai prestasi tertentu, seperti untuk mengikuti pertandingna atau perlombaan, Sedangkan yang sifat non kompetitif, lebih menekankan pada sifat kemauan siswa tampa terikat dengan maksud-maksud bersaing untuk mengungguli pihak lain.

\subsection{Tujuan Kegiatan Ekstrakurikuler}

Tujuan ekstrakurikuler menurut kurikulum SD Depdiknas (1990:8-9) adalah sebagai berikut:

1) Kegiatan ekstrakurikuler harus dapat meningkatkan pengetahuan siswa beraspek kognitif dan psikomotor,

2) Mengembangkan bakat serta Partisipasi Siswa dalam upaya membina pribadi menuju pembinaan manusia seutuhnya yang positif,

3) Dapat mengetahui, mengenal serta membedakan hubungan antara suatu mata pelajaran dengan mata pelajaran lain.

Lebih jauh dijelaskan bahwa ekstrakurikuler sebagai jalur pembinaan kesiswaan mempunyai peranan utama sebagai berikut:

1) Untuk memperdalam dan memperluas pengetahuan siswa, dalam arti memperkaya, mempertajam, serta memperbaiki pengetahuan para siswa yang berkaitan dengan mata pelajaran sesuai dengan kurikulum yang ada.

2) Untuk melengkapi upaya pembinaan, pemantapan dan pembetulan nilai $\neg$ nilai kepribadian siswa.

3) Disamping berorientasi pada mata pelajaran yang diprogramkan usaha pemantapan dan pembentukan kepribadian siswa, banyak kegiatankegiatan ekstrkurikuler lain yang di arahkan membina serta meningkatkan bakat, minat dan ketrampilan. Hasil yang diharapkan dari kegitan ini adalah untuk memacu anak kearah kemampuan mandiri, percaya diri dan kreatif Depdikbud (1988:5).

Selain memiliki peran, kegiatan ekstrakurikuler juga memiliki tujuan utama yaitu agar:

1) Siswa dapat memperdalam dan memperluas pengetahuan, mengenal hubungan antara berbagai mata pelajaran, menyalurkan bakat dan minat, serta melengkapi upaya pembinaan manusia seutuhnya dalam arti: (a). Beriman dan bertaqwa kepada Tuhan Yang Maha Esa (b). Berbudi pekerti luhur (c). Memiliki pengetahuan dan ketrampilan (d). Sehat jasmani dan rohani (e). Berkepribadian yang mantap dan mandiri (f). Memiliki rasa tanggungjwab kemasyarakatan dan kebangsaan.

2) Untuk lebih memantapkan pendidikan kepribadian dan untuk lebih mengaitkan antara pengetahuan yang diperoleh dalam program kurikulum dengan keadaan dan kebutuhan lingkungan.

Sebagai mana yang telah dikemukan kan oleh Lutan (1986: 17), yang mengatakan bahwa: "pengembangan tujan ekstrakurikuler berpijak pada kebutuhan manusia, oleh karena itu ada lima dimensi kebutuhan manusia yaltu; (1) Fisikal; (2) Emosional; (3) Sosial (4) Intelektual (5) Spritual. Dalam hal ini setiap orang menbutukan untuk tumbuh dan matang dalam setiap dimensi itu". Pendapat ini dapat disimpulkan bahwa kelima macam kebutuhan ini menjadi 
dorongan siswa dalam mengikuti kegiatan ekstrakurler.

\subsection{Ciri-Ciri Kegiatan Ekstrakurikuler}

Menurut Syrifudin dan Asmun (1982:45) atau lima ciri-ciri kegiatan ekstra kurikuler antara. lain:

1) Menerapkan kegiatan yang berkaitan atau hubungan langsung dengan kurikulum sekolah, artinya mempunyai pengaruh terhadap pencapaian tujuan kurikulum.

2) Diberikan di luar jam pelaJaran diawasi yang bertanggung jawab tentang bidang pelajaran tersebut.

3) Mempunyai objek yang sama atau sasaran yang sama, yaitu anak didik, Mulai kegiatan ekstrakurikuler dibina suatu kesatuan individu yang utuh, Ekstrakurikuler dapat berupa olahraga, Kesenian, pramuka darmawisata rekreasi dan beberapa macam kegiatan yang dapat mempengaruhi terhadap kesempurnaan proses dan keberhasilan proses, belajar mengajar.

\subsection{Ekstrakurikuler Olahraga}

\subsubsection{Olahraga}

Olahraga adalah latihan gerakan atau gerakan badan yang berfungsi untuk menguatkan dan menyehatkan badan seperti sepak bola, berenang, lempar lembing dan sebagainya (Poerwadarminta, 1986:766). Dalam federatiaon on sport yang di keluarkan di UNESCO, di berikan batasan dan di kemukakan batasan yang di susun oleh majelis internasional olahraga dan pendidikan jasmani (international council of sportnd hisical education / ICSPE pendidikan jasmani adalah suatu proses pendidikan yang diarahkan untuk mendorong, membimbing dan membina kemampuan jasmaniah dan rohaniah, serta kesehatan siswa dan lingkungan agar tumbuh, berkembang secara harmonis dan optimal sehingga mampu melaksanakan tugas bagi dirinya sendiri dan pembangunan bangsa (Depdikbud, 1990:1) Batasan pendidikan jasmani yang dilakukan oleh UNNESCO dalam internasional chater of physicial education and sport yang dikutip (Abdulkadir Ateng, 1975:8) suatu proses pendidikan seseorang sebagai individu maupun seorang anggota masyarakat yang melaksanakan secara sadar dan sistematik melalui berbagai kegiatan jasmani dalam rangka memperoleh peningkatan kemampuan dan ketrampilan jasmani kecerdasan, dan pembentukan watak Yang dimaksud olahraga dalam skripsi adalah kegiatan olahraga pendidikan jasmani yang sering dilakukan di sekolah-sekolah yang diajarkan oleh seorang guru mata pelajaran pendidikan jasmani atau seorang pelatih yang meliputi: bermain, latihan jasmani, dan kompetisi.

Sejalan dalam kegiatan ekstrakurikuler yang telah disajikan pada halaman terdahulu berarti untuk memilih kegiatan ekstrakurikuler utamanya pada kegiatan ekstrakurikuler olahraga masing-masing sebaiknya memiliki modal keterampilan sebagai potensi dari yang perlu dikembangkan melalui kegiatan ekstrakurikuler yang diselenggarakan oleh masing-masing sekolah pada umumnya mereka memiliki kegiatan ekstrakurikuler olahraga yang akan dipilih potensi yang dimaksud seperti macam $\neg$ macam keterampilan yang telah dimiliki dan dikuasai pada cabang yang akan di pilih Macam-macam

kegiatan ekstrakurikuler olahraga yang disediakan oleh sekolah umumnya cabang-cabang olahraga yang sering dikompetisikan antar sekolah, sehingga hasil dari kegiatan ekstrakurikuler dapat bermanfaat untuk menghadapi berbagai kejuaraan berbagai cabang olahraga sebagai pilihan dalam kegiatan ekstra kurikuler olahraga maka akan mendorong siswa untuk memilihnya sesuai dengan bakat.

2.4.2 Faktor Pendukung Kegiatan Ekstrakurikuler

Pelaksanaan kegiatan ekstrakuri kuler berlangsung sesuai dengan harapan semua pihak yang terlibat dalam proses pendidikan disekolah maka banyak faktor pendukung 
keberhasilan kegiatan tersebutdiantaranya ialah:

\section{Kepala sekolah}

Kepala sekolah sebagai peimpinan lembaga pendidikan sepenuhnya harus mendukung kegiatan ekstrakurikuler, dengan adanya dukungan akan menimbulkan kegiatan tersebut dengan sepenuhnya dan keyakinan.

2. Guru/pendidik

Guru yang ada disekolah dapat memberikan dukungan kepada siswa untuk mengikuti kegiatan ekstrakurikuler, khususnya guru penjskes dapat menberikan penjelasan tentang tujuan dan mamfaat mengikuti kegiatan ekstrakurikuler keterlibatan guru maka siswa lebih berminat mengikuti kegiatan ekstrakurikuler.

3. Sarana dan prasarana

Sarana dan perasarana yang tersedia disekolah merupekan faktor pendukung ekstra kurikuler olahraga, jika sarana dan prasarana kurang memadai atau tidak mencukupi sesuai dengan cabag olahraga, akan mengurangi motivasi siswa untuk mengikuti olahraga tersebut.

4. Partisipsi siswa

Tingkat partisipasi siswa juga menjadi pendukung pelaksanaan ekstrakurikuler olahraga disekolah jika tingkat partisipasi siswa tinggi maka kegiatan ekstrakurikuler akan dampak lebih hidup. Untuk menghindari penurunan Partisipasi Siswa.

\section{Metode Penelitian}

Jenis Penelitian

Penelitian ini dapat dikatagorikan dalam penelitan deskriptif, yaitu "penelitian yang mengambarkan peristiwa yang terjadi, atau fenomena yang ada pada masa sekarang". Dalam hal ini Arikunto (1993:209) mengatakan bahwa: "Penelitian deskriptif mempelajari tentang masalah mansyarakat serta situasi tertentu, sikap, pandangan dan proses yang berlangsung serta pengaruh dari fenomena tertentu".

\section{Populasi dan Sampel Penelitian}

Populasi dalam penelitian ini adalah seluruhan iswa kelas VI SD Negeri Pasi Rawa Kecamatan Pidie Kabupaten Pidie yang berjumlah 32 orang siswa, mengingat jumlah populasi yang relatif sedikit dan terjangkau sehingga dari seluruh siswa kelas VI SD Negeri Pasi Rawa Kecamatan Pidie Kabupaten Pidie akan dijadikan sampel dalam penelitian ini (total sampel).

\section{Tehnik Pengumpulan Data}

Untuk mengumpul data penulis mengunakan penelitian lapangan dengan cara menyebarkan angket yang berisikan beberapa pertanyaan seputar tanggapan siswa terhadap mamfaat kegiatan ekstrakurikuler yang dilaksanakan di sekolah

\section{Tehnik Analisis Data}

Untuk perhitungan persentase dari semua altemativ jawaban pada setiap pertanyaan sehinga menjadi suatu konsep yang dapa diambil kesimpulan, maka penulis mengambila tatistik sederhana dengan metode distribusi frekuensi dalam menganalisis data yang diperoleh hasil yang diperoleh akan dianalisis dengan mengunakan irumus: Rumus mencari persentase

$$
\mathrm{P}=\frac{F}{N} x 100 \%
$$

Kemudian data tersebut dideskripsikan serata di tapirkan untuk dapat diambil kesimpulan terhadap pertanyaan penelitian. Dalam memberi penafsiran dimulai dari bilangan terbesar sampai bilangan terkecil dengan sebagai berikut:

$100 \%$ : Disebut seluruhnya

80-99\% : Disebut pada umumnya

60-79\% : Disebut sebagian besar

$50-59 \% \quad$ : Disebut lebih dari setengah

40-32\% : Disebut kurang dari setegah

20-39 : Disebut sebahagian kecil

0-19\% : : Disebut sedikit sekali

\section{Hasil Penelitian}

Kegiatan ekstrakurikuler adalah sebagai alat yang amat penting untuk tercapai tujuan-tujuan pendidikan yang berati dan 
tidak sekedar untuk menjadi sumber-sumber hiburan bagi murid, kegiatan ekstrakurikuler adalah suatu kegiatan yang dilakukan pada jam diluar sekolah (dilakukan termasuk hari libur) yang dilakukan di luar sekolah dan bertujuan memperluas pengetahuan siswa, mengenal dan menambah berbagai kegiatan olahraga, menyalurkan bakat dan minat serta melengkapi upaya pembinaan seutuhnya, ekstrakurikuler adalah kegiatan untuk membantu memperlancar perkembangan individu murid sebagai manusia seutuhnya, sehingga ia akan mempu mengembangkan potensi dirinya dengan baik, yang selama ini belum tergali atau belum ia temukan tentang potensi yang ia miliki.

Kegiatan ekstakurikuler olahraga, dilaksanakan di SD Negeri Pasi Rawa Kecamatan Pidie Kabupaten Pidie dalam perspektif siswa merupakan suatu temapat untuk mengembangkan bakat dan potensi peserta mereka kearah yang lebih baik dan bermamfaat bagi dirinya sendiri, bangsa dan negara serta, serta bagi masyarakat. Hasil penelitian menunjukan bahwa 59,30 atau lebih dari setengah siswa senang mengikuti kegiatan ekstrakurikuler olahraga di sekolah, serta memberi tanggapan yang positif terhadap mamfaat kegiatan ekstrakurikuler olahraga yang dilaksanakan di sekolah.

Menburut siswa hal ini disebabkan dengan mengikuti kegiatan ekstrakurikuler olahraga yang di adakan disekolahnya dapat meningkatkan prestasi dalam bidang olahraga, disamping itu siswa mengikuti kegiatan ekstrakurikuler olahraga juga ingin mendapat penghargaan dari para guru atas prestasi mereka, serta kegiatan tersebut merupakan sebuah keinginan yang timbul dari dalam diri siswa tanpa unsur paksaan pihak lain, dalam hal ini guru, orang tua maupun teman di sekolahnya. Tentu hal ini berdasarkan pemahaman siswa akan pentingnya sebuah prestasi olahraga dalam mendukung keberhasilan cita cita nya kelak.

\section{Simpulan}

Bedasarkan data dan hasil penelitian

"Tanggapan Siswa Terhadap Manfaat
Kegiatan Ekstrakurikuler Olahraga dalam Pengembangan Prestasi dan Potensi Diri" maka dapat disimpulkan:

a Sebanyak 59,30\% siswa atau lebih dari setengah siswa senang mengikuti dan melibatkan diri berpartisipasi aktif dalam kegiatan ekstrakurikuler olahraga yang dilaksakan setiap kahir semester di sekolah mereka.

b Secara umum siswa tersebut telah memiliki tanggapan yang positif terhadap kegiatan ektrakurikuler olahraga, dalam arti mereka meyakini kegiatan tersebut dapat meningkatkan prestasi dan potensi dasar olahraga yang telah mereka miliki.

\section{Saran}

a Adanya suatu pengamatan yang kuat tentang proses kegiatan ekstrakurikuler olahraga yang dilaksanakan disekolah dengan harapan dapat meningkatkan prestasi siswa kedepannya dalam mengikuti berbagai pertandingan maupun perlombaan olahraga yang diselenggarakan.

b Hendaknya adanya dorongan bagi siswa untuk mengikuti kegiatan ekstrakurikuler olahraga yang mereka ikuti baik dorongan dari orang tua maupun dari guru supaya kedepanya lebih bersemnagat mengikuti kegiatan ekstrakurikuler olahraga yang diselenggarakan disekolah untuk lebih meningkatkan prestasi olahraga kedepannya.

c Hendaknya dalam kegiatan ekstrakurikuler olahraga tidak hanya mengutamakan kegiatan pertandingan semata, akan tetapi harus dilaksanakan kegiatan-kegiatan yang bersifat pelatihan dan pembinaan tehnik maupun ketrampilan siswa, pembinaan yang dilakukan sejak dini akan dimungkinkan memporelh prestasi dimasa mendatang.

d Macam-macam kegiatan ekstrakurikuler olahraga yang disediakan oleh sekolah namun sebaiknya cabang-cabang olahraga yang sering dikompetisikan antar sekolah, sehingga hasil dari 
kegiatan ekstrakurikuler dapat bermanfaat untuk menghadapi berbagai kejuaraan berbagai cabang olahraga sebagai pilihan dalam kegiatan ekstrakurikuler olahraga, sehingga akan mendorong siswa untuk memilihnya sesuai dengan bakat yang mereka miliki.

\section{DAFTAR PUSTAKA}

Arismunandar, Wismoyo (1997). Pembinaan Permasalahan Olahraga. Jakarta: KONI 2005 Undang-undang RI No. 3 tahun 2005 tentang sistem keolahragaan nasional.

Depdiknas (2001) Kurikulum Berbasis Kompetensi SM, balitang; Jakarta

Dimyati \& Mujiono. (2006). Belajar dan Pembelajaran. Jakarta: Rineka Cipta.

Jamaris Martini, (2010). Orientasi Baru dalam Psikologi Pendidikan, Jakarta Pusat: Yayasan Penamas Murni.

Komarudin dan Yusuf Hidayat, (2006). Psikologi Olahraga. Latihan Mental dalam Olahraga Kompetitif. Bandung; PT Remaja Rosdakarya.

Magill A. Richard, (2011). Motor Learning and Control Concepts an Aplication, New York University Mc Graw Hill Companies, Inc.

Muhajir, (2013). Pendidikan Jasmani Olahraga dan Kesehatan Untuk SMA Kelas XII, Jakarta : Erlangga.
Ngalim Purwanto. (2007). Psikologi Pendidikan, Bandung: Rosdakarya

Oemar Malik, (2004). Proses Belajar Mengajar, Jakarta: PT Bumi Aksara.

Supartono, (2000). Sarana Dan Prasarana Olahraga. Jakarta Departemen Pendidikan jasmani

Sanjaya Wina, (2013). Strategi Pembelajara Berorientasi Standar Proses Pendidikan, Jakarta: Kencana Prenadamedia.

Sardiman, (2011). Interaksi dan Motivasi Belajar Mengajar. Jakarta: Rajawali Pers.

Gunarsa D. Singgih, (2008). Psikologi Olahraga Prestasi, Jakarta: Gunung Mulia.

Siregar Eveline, (2010). Teori Belajar dan Pembelajaran, Bogor: Ghalia Indonesia, .

Sukadianto, (2010). Muluk Dangsina, Pengantar Teori dan Metodogi, Melatih Fisik, Bandung: Lubuk Agung, .

Surahkmad Winarno, (2004). Pengantar Penelitian Ilmiah, Bandung :Tarsito,

Suryabrata Sumadi, (2013). Psikologi Pendidikan, Jakarta:Rajawali. 